\title{
PENGARUH KOMBINASI MODEL PROBLEM BASED LEARNING DENGAN TEAM GAMES TOURNAMENT TERHADAP HASIL DAN MINAT BELAJAR GEOGRAFI SISWA MAN REJOTANGAN KABU- PATEN TULUNGAGUNG
}

\author{
Rika Hajizah Purba ${ }^{1}$, Ach. Fatchan ${ }^{2}$, Singgih Susilo ${ }^{3}$ \\ Email: Rikahajizahpurba@yahoo.co.id, ach.fatchan.fis@um.ac.id, \\ singgih.susilo.fis@um.ac.id
}

\begin{abstract}
Abstrak: Penelitian ini bertujuan untuk mengetahui pengaruh kombinasi model pembelajaran Problem Based Learning dengan Team Games Tournament terhadap hasil dan minat belajar siswa kelas XI IPS MAN Rejotangan Kabupaten Tulungagung. Rancangan penelitian yang digunakan adalah quasi eksperimen dengan pre-test post-test non equaivalent control group design. Variabel bebas yang digunakan adalah kombinasi model pembelajaran Problem Based Learning dengan Team Games Tournament, variabel terikat yang digunakan adalah hasil dan minat belajar. Subjek penelitian adalah siswa kelas XI IPS MAN Rejotangan Kabupaten Tulungagung. Subjek utama sebagai kelas eksperimen adalah kelas XI IPS 1 dengan menggunakan kombinasi model pembelajaran Problem Based Learning dengan Team Games Tournament,dan sebagai kelas kontrol adalah kelas XI IPS 2 dengan menggunakan ceramah, tanya jawab, dan pemberian tugas. Instrumen yang digunakan untuk mengukur hasil belajar adalah soal, sedangkan untuk mengukur minat belajar adalah angket. Kedua instrumen diuji validasi terlebih dahulu oleh ahli. Uji validasi, reliabilitas, tingkat kesukaran dan daya beda diperuntukkan instrumen hasil belajar. Pengujian hipotesis menggunakan uji ANAKOVA dengan taraf signifkansi 0,05. Hasil penelitian menunjukkan: 1) ada pengaruh mean hasil belajar antara kelas eksperimen dengan kelas kontrol, $\mathrm{t}=4,509$ dan signifikansi dua ekor 0,000, sehingga $\mathrm{p}<0,05 ; 2$ ) ada pengaruh minat belajar antara kelas eksperimen dengan kelas kontrol, nilai $\mathrm{t}=$ 5,854 dan signifikansi dua ekor 0,000 , sehingga $\mathrm{p}<0,05$.
\end{abstract}

Kata Kunci: Kombinasi Model Pembelajaran Problem Based Learning dengan Team Games Tournament, Hasil Belajar, Minat Belajar.

\section{PENDAHULUAN}

Pembelajaran geografi memerlukan peran aktif siswa baik individu maupun kelompok agar mudah dalam mengkaji dan memahami materi yang dipelajari. Faktanya dalam pembelajaran geografi siswa hanya mendengarkan penjelasan dari guru dan membaca buku teks. Siswa kurang memeroleh kesempatan untuk mengembang-

\footnotetext{
${ }^{1}$ Mahasiswa Pasca UM

${ }^{2}$ Dosen Jurusan Geografi FIS UM

${ }^{3}$ Dosen Jurusan Geografi FIS UM
}

kan kemampuan menyampaikan ide atau gagasannya sehingga cenderung pasif. Pembelajaran yang cenderung pasif menyebabkan siswa kurang tertarik pada mata pelajaran geografi sehingga mempengaruhi hasil belajar. Solusi yang dilakukan adalah dengan memilih pembelajaran kooperatif. Slavin (2005:4) mengata- 
kan bahwa "penggunaan pembelajaran kooperatif untuk meningkatkan pencapaian prestasi para siswa".

Saat ini Pembelajaran di sekolah telah menerapkan pembelajaran berbasis scientific Approach, merupakan satu pendekatan yang digunakan dalam pembelajaran dengan menitikberatkan pada penggunaan metode ilmiah dalam kegiatan belajar mengajar. Pendekatan ini bertujuan agar siswa berpikir ilmiah, logis, kritis dan objektif sesuai dengan fakta yang ada. Pembelajaran Scientific Approach mencakup 5 aspek, yaitu: observing, questioning, associating, experimenting, networking. Permasalahan yang ada adalah sintaks pembelajaran kooperatif belum mencakup 5 aspek pada Scientific Approach, sehingga untuk menerapkannya diperlukan improvisasi model pembelajaran. Guru dituntut kreatif untuk mengembangkan model pembelajaran sebagai alternatif pemecahan masalah di dalam kelas. Dalam hal ini mengkombinasikan model pembelajaran menjadi salah satu cara agar pembelajaran kooperatif sesuai dengan Scientific Approach. Upaya yang dilakukan adalah mengkombinasikan model pembelajaran Team Games Tournament dengan Problem Based Learning untuk mengatasi hasil belajar rendah yang disebabkan oleh minat belajar yang rendah.

Model TGT memiliki desain fleksibel, yakni kinerja individu yang bertujuan memberikan kontribusi untuk kinerja kelompok (Devries, 1976). Setiap siswa akan peduli terhadap tugas yang diberikan karena merasa memiliki tanggung jawab bagi keberhasilan kelompok. Tanggung jawab terhadap keberhasilan kelompok menjadikan siswa berusaha lebih ba- ik dalam menyelesaikan tugas. Selain itu, model TGT dapat membuat siswa senang dalam belajar. Hal ini disebabkan oleh pelaksanaan game aka-demik, sesuai dengan pernyataan (Ehlers, 2004) "Melaksanakan pembela-jaran dalam bentuk permainan dapat membuat siswa merasa senang".

Model Problem Based Learning (PBL) adalah model pembelajaran yang berfokus pada pembelajaran yang menggunakan masalah dunia nyata sebagai suatu konteks bagi siswa untuk belajar melalui berpikir kritis dan keterampilan pemecahan masalah. Hal ini bertujuan untuk memperoleh pengetahuan dan konsep yang sesuai dari materi pelajaran, sehingga memberi peluang siswa bekerja secara penuh dengan kemampuan belajar mereka. Sebagaimana yang dikemukakan oleh (Ibrahim, 2000 dalam Sumarmi, 2012) "Pembelajaran berbasis masalah bertujuan atau berguna untuk merancang siswa berpikir tingkat tinggi dalam situasi orientasi masalah".

Berdasarkan penelitian yang dilakukan oleh penemu model $P B L$ dan $T G T$, kombinasi dari kedua model pembelajaran tersebut dapat diterapkan di sekolahsekolah yang memiliki permasalahan hasil belajar rendah yang disebabkan minat belajar rendah. Hal ini sesuai dengan pernyataan Soemanto (1983:3) "pendidikan menghendaki agar pengajaran memperhatikan minat, kebutuhan dan kesiapan anak didik untuk belajar". Permasalahan minat belajar siswa yang rendah disebabkan oleh rasa ketertarikan pada mata pelajaran rendah. Permasalahan tersebut dapat diatasi dengan menerapkan model pembelajaran menyenangkan yang sesuai dengan Kurikulum 2013. Hal ini perlu diterapkan 
Rika Hajizah Purba, Ach. Fatchan, Singgih Susilo. Pengaruh Kombinasi Model Problem Based Learning Dengan Team Games Tournament Terhadap Hasil Dan Minat Belajar Geografi Siswa MAN Rejotangan Kabupaten Tulunggung

perpaduan antara model pembelajaran Problem Based Learning dengan Team Games Tournament.

Peneliti memilih menggunakan kombinasi model pembelajaran Problem Based Learning dengan Team Games Tournament didasarkan pada beberapa alasan. Alasan-alasan tersebut, yaitu: 1) mengembangkan model pembelajaran kooperatif agar sesuai dengan pembelajaran Scientific Approach; 2) kombinasi model pembelajaran Problem Based Learning dengan Team Games Tournament merupakan model pembelajaran kooperatif berbasis konstruktivisme yang menyenangkan karena terdapat turnamen pada pembelajaran ini; 3) siswa akan belajar secara mendalam untuk memahami konsep dan mengembangkan kreativitas dalam pemecahan masalah; 4) siswa menjadi lebih aktif terlibat dalam belajar mereka sendiri dan berpartisipasi lebih bebas ketika berdiskusi; 5) mengembangkan kepemimpinan siswa dan mengajarkan mereka terampil berdiskusi dan bekerja dalam kelompok; 6) memberikan kesempatan untuk mengembangkan rasa hormat bagi anggota kelompok yang bekerja membantu kemajuan kelompok dalam mencapai tujuan mereka; 7) strategi ini dapat digunakan di sekolah-sekolah yang melakukan berbagai macam pengaturan kelas dan pengelompokan siswa; 8) memberi kesempatan kepada siswa untuk lebih intensif meneliti (mencari dan menemukan) suatu permasalahan. Adapun rumusan masalah yang diambil dari latar belakang penelitian, yaitu 1) Apakah kombinasi model pembelajaran Problem
Based Learning dengan Team Games Tournament berpengaruh secara signifikan terhadap hasil belajar geografi siswa kelas XI IPS MAN Rejotangan? 2) Apakah kombinasi model pembelajaran Problem Based Learning dengan Team Games Tournament berpengaruh secara signifikan terhadap minat belajar geografi siswa kelas XI IPS MAN Rejotangan?

\section{METODE PENELITIAN}

Penelitian ini termasuk dalam $q u$ asi eksperimen, dengan mengambil dua kelas yang memiliki kemampuan akademik relatif sama (setara). Selanjutnya untuk menentukan kelas eksperimen dan kelas kontrol ditentukan secara acak. Desain penelitian ini adalah pretest-posttest control group. Kedua kelas penelitian, baik kelas eksperimen maupun kelas kontrol, diberi pre-test sebelum dilaksanakan pembelajaran yang bertujuan untuk mengetahui kemampuan awal siswa, selanjutnya penyampaian materi di mana dalam penyampaian materi kelas eksperimen menggunakan kombinasi model Problem Based Learning dengan Team Games Tournament, sedangkan kelas kontrol menggunakan pembelajaran ceramah, tanya jawab, dan pemberian tugas (konvensional). Selanjutnya pada akhir pembelajaran kedua kelas tersebut diberi post-test untuk mengukur hasil belajar, dan pemberian angket untuk mengukur minat belajar. Berikut kisi-kisi soal yang digunakan untuk mengukur hasil belajar geografi siswa. 
Tabel 1. Kisi-kisi Soal Pre-test dan Post-test

\begin{tabular}{|l|l|l|}
\hline $\begin{array}{l}\text { No } \\
\text { Soal }\end{array}$ & Soal & Ranah Kognitif \\
\hline 1 & $\begin{array}{l}\text { Pilihlah 1 dari 5 wacana di atas, tuliskan permasalahan lingkungan yang } \\
\text { ada di Tulungagung? }\end{array}$ & C2 \\
\hline 2 & $\begin{array}{l}\text { Rumuskan permasalahan tersebut dalam bentuk pertanyaan? (Pilihan no- } \\
\text { mor 1) }\end{array}$ & C2 \\
\hline 3 & $\begin{array}{l}\text { Dalam wacana tersebut, berikan pendapat dan identifikasi beberapa alter- } \\
\text { natif tentang upaya pelestarian lingkungan di kabupaten Tulungagung? }\end{array}$ & $\mathrm{C} 4$ \\
\hline 4 & Pilihlah satu alternatif pemecahan masalah yang terbaik? & $\mathrm{C} 2$ \\
\hline 5 & Apa kesimpulan dari alternatif pemecahan yang anda pilih? & $\mathrm{C} 4$ \\
\hline
\end{tabular}

Subjek dalam penelitian ini adalah siswa kelas XI IPS MAN Rejotangan Kabupaten Tulungagung semester genap tahun ajaran 2015/2016 yang terdiri dari dua kelas. Dari dua kelas tersebut diambil satu kelas sebagai kelas eksperimen, yaitu kelas XI IPS 1 yang mendapat perlakuan dengan menggunakan kombinasi model $P B L$ dengan $T G T$, dan satu kelas sebagai kelas kontrol yaitu kelas XI IPS 2 dengan menggunakan pembelajaran ceramah, tanya jawab, dan pemberian tugas.

Data yang digunakan dalam penelitian ini adalah hasil belajar dan minat belajar. Hasil belajar diambil dengan cara melakukan tes. Instrumen dalam penelitian ini menggunakan soal tes. Tes untuk pretest dan postest berupa tes subjektif dengan ranah $\mathrm{C} 4$ menurut taksonomi Bloom dengan pertimbangan untuk mengetahui kemampuan hasil belajar siswa. Pengujian instrumen penelitian ini meliputi: validitas, reliabilitas, tingkat kesukaran, dan daya beda. Sedangkan pengambilan data minat belajar diperoleh dari pengisian angket yang telah divalidasi oleh ahli. Pengujian dalam penelitian ini menggunakan bantuan program SPSS 16.0 for Windows.

Metode analisis data menggunakan metode uji statistik. Data yang dianalisis untuk mengukur hasil belajar, yaitu data kemampuan awal siswa, data kemampuan akhir siswa, dan data gain score siswa. Sedangkan data untuk mengukur minat belajar siswa yaitu perolehan skor dari pengisian angket. Setelah data terkumpul, maka langkah selanjutnya adalah uji prasyarat analisis dilanjutkan uji hipotesis. Uji prasyarat meliputi uji normalitas, dengan menggunakan uji KolmogorovSmirnov, dan uji homogenitas dengan menggunakan uji Levene's. Uji hipotesis ini bertujuan untuk mengetahui apakah hipotesis diterima atau ditolak. Analisis yang digunakan untuk menguj hipotesis ini adalah dengan uji $t$ indenpenden (independent sample t-test) satu sisi dengan taraf kepercayaan $95 \%$. Analisis data, baik uji prasyarat maupun uji hipotesis, menggunakan bantuan program SPSS 16.0 for Windows.

\section{HASIL PENELITIAN}

\section{Hasil Belajar}

\section{Pre Test}

Data kemampuan awal diperoleh dari skor hasil tes kelas kontrol dan kelas eksperimen sebelum diberi perlakuan (pretest). Analisis statistik deskriptif data kemampuan awal siswa dapat dilihat pada Tabel 2. 
Tabel 2 Deskriptif Data Tes Awal (Pretest) Hasil Belajar

\begin{tabular}{lcccc}
\hline Kelas & N siswa & Nilai Minimum & Nilai Maksimum & Rata-Rata \\
\hline Eksperimen & 22 & 40 & 80 & 59,1 \\
\hline Kontrol & 24 & 35 & 70 & 55,2 \\
\hline
\end{tabular}

Berdasarkan Tabel 2 dapat diketahui pre-test kedua kelas mempunyai rata-rata yang tidak jauh berbeda, di mana kelas kontrol mempunyai rata-rata sebesar 55,2 sedangkan kelas eksperimen mempunyai rata-rata sebesar 59,1. Perbedaan rata-rata yang kecil menunjukkan bahwa kemampuan awal kedua kelas adalah setara.

\section{Post Test}

Data kemampuan akhir diperoleh dari hasil tes kelas kontrol dan kelas eksperimen setelah diberi perlakuan (postest). Analisis statistik deskriptif data kemampuan akhir siswa dapat dilihat pada Tabel 3.

Tabel 3 Deskriptif Data Tes Akhir (Posttest) Hasil Belajar

\begin{tabular}{lcccc}
\hline Kelas & $\sum$ siswa & Nilai Minimum & Nilai Maksimum & Rata-Rata \\
\hline Eksperimen & 22 & 65 & 95 & 78,4 \\
\hline Kontrol & 24 & 45 & 90 & 56 \\
\hline
\end{tabular}

Berdasarkan Tabel 3 dapat diketahui bahwa kemampuan akhir kedua kelas mempunyai rata-rata yang berbeda, di mana kelas kontrol mempunyai rata-rata sebesar 56, sedangkan kelas eksperimen mempunyai rata-rata sebesar 78,4. Perbedaan rata-rata yang cukup besar menunjukkan bahwa kemampuan akhir kedua kelas adalah berbeda. Hal ini dikarenakan pada kegiatan pembelajaran kelas eksperimen menggunakan kombinasi model pembelajaran Problem Based Learning dengan Team Games Tournament, sedangkan kelas kontrol menggunakan pembelajaran ceramah, tanya jawab, dan pemberian tugas (konvensional).

\section{Gain Score}

Gain score diperoleh dari selisih nilai siswa yaitu nilai kemampuan akhir (post-test) dikurangi nilai kemampuan awal (pre-test). Analisis statistik deskriptif data gain score siswa dapat dilihat pada Tabel 4.

\section{Tabel 4 Deskriptif Data Gain Score Hasil Belajar}

\begin{tabular}{lcccc}
\hline Kelas & $\sum$ siswa & Nilai Minimum & Nilai Maksimum & Rata-Rata \\
\hline Eksperimen & 22 & 0 & 40 & 19,3 \\
\hline Kontrol & 24 & -5 & 20 & 6,25 \\
\hline
\end{tabular}

${ }^{1}$ Mahasiswa Pasca UM 
Berdasarkan Tabel 4 dapat diketahui bahwa gain score kedua kelas mempunyai rata-rata yang berbeda, di mana kelas kontrol mempunyai rata-rata sebesar 6,25 sedangkan kelas eksperimen mempunyai rata-rata sebesar 19,3. Perbedaan rata-rata yang cukup besar menunjukkan bahwa gain score kedua kelas adalah berbeda.

\section{Minat Belajar}

Data minat belajar diperoleh dari skor angket yang diisi oleh siswa setelah perlakuan. Skor ini menggambarkan minat belajar geografi dari kedua subjek, baik kelas eksperimen maupun kelas kontrol. Data hasil pengisian angket belajar yang didapat kemudian dianalisis untuk mengetahui distribusi frekuensi sesuai kualifikasi yang telah ditentukan. Berikut merupakan hasil pengisian angket minat belajar geografi di kelas eksperimen dan kelas kontrol.

Tabel 5 Distribusi Frekuensi Skor Minat Belajar Geografi Kelas Eksperimen dan Kontrol

\begin{tabular}{lcccccccc}
\hline \multirow{2}{*}{ Kelas } & \multicolumn{2}{c}{ Rendah } & \multicolumn{2}{c}{ Sedang } & \multicolumn{2}{c}{ Tinggi } & \multicolumn{2}{c}{ Jumlah } \\
\cline { 2 - 8 } & Frekuensi & $(\%)$ & Frekuensi & $(\%)$ & Frekuensi & $(\%)$ & Frekuensi & $(\%)$ \\
\hline Eksperimen & 0 & 0 & 5 & 22,7 & 17 & 77,3 & 22 & 100 \\
Kontrol & 2 & 8,3 & 19 & 79,2 & 3 & 12,5 & 24 & 100 \\
\hline
\end{tabular}

Berdasarkan tabel di atas, hasil penelitian minat belajar pada kelas eksperimen dan kontrol terdapat perbedaan. Sebagian besar kelas eksperimen memiliki kualifikasi minat belajar geografi tinggi dengan jumlah 17 siswa atau 77,3\%. Sedangkan sebagian besar kelas kontrol memiliki kualifikasi minat belajar geografi sedang dengan jumlah 19 siswa atau $79,2 \%$.

\section{Uji Hipotesis}

Pengujian hipotesis merupakan langkah untuk menentukan apakah hipotesis diterima atau ditolak. Data yang digunakan untuk uji hipotesis adalah data gain score untuk hasil belajar, dan total skor untuk minat belajar. Sebelum melakukan uji hipotesis, terlebih dahulu data dari kedua variabel di uji prasyarat. Hasil uji prasyarat untuk hasil dan minat belajar siswa (uji normalitas dan uji homogeni- tas) diketahui bahwa data tersebut terdistribusi secara normal dan kedua sampel berasal dari populasi yang mempunyai varians yang sama (homogen). Karena data normal dan homogen, maka uji hipotesis dilakukan dengan menggunakan statistik parametrik yaitu dengan uji-t (independent sample t-test) dengan bantuan SPSS 16.0 for Windows.

Dari hasil uji-t terhadap hasil dan minat belajar siswa didapatkan bahwa nilai probabilitas (sig. 2-tailed) adalah 0,000 . Dari hasil tersebut nilai probabilitas (sig. 2-tailed) $<0,05$, maka $\mathrm{H}_{0}$ ditolak atau dengan kata lain hasil dan minat belajar siswa kelas XI IPS yang mengikuti pembelajaran dengan kombinasi model $P B L$ dengan $T G T$ lebih tinggi dari pada siswa yang menggunakan pembelajaran ceramah, tanya jawab dan pemberian tugas (konvensional) di MAN Rejotangan Kabupaten Tulungagung. 
Rika Hajizah Purba, Ach. Fatchan, Singgih Susilo. Pengaruh Kombinasi Model Problem Based Learning Dengan Team Games Tournament Terhadap Hasil Dan Minat Belajar Geografi Siswa MAN Rejotangan Kabupaten Tulunggung

\section{PEMBAHASAN}

Temuan dalam penelitian ini menunjukkan bahwa kombinasi model pembelajaran Problem Based Learning (PBL) dengan Team Games Tournament (TGT) berpengaruh terhadap hasil dan minat belajar geografi siswa MAN Rejotangan pada materi lingkungan hidup. Hasil dan minat belajar terdapat perbedaan rata-rata nilai antara kelas eksperimen dan kelas kontrol, sehingga dinyatakan model pembelajaran tersebut berpengaruh positif terhadap hasil dan minat belajar geografi siswa MAN Rejotangan. Kondisi ini terjadi karena perbedaan perlakuan dalam pembelajaran diantara kelas eksperimen dan kelas kontrol. Hal tersebut sejalan dengan temuan Mirza (2009), yakni perpaduan metode pembelajaran berbasis masalah dan turnamen permainan tim mampu meningkatkan hasil belajar. Pendapat yang sama juga disampaikan oleh Utami (2014), yaitu terdapat perbedaan yang signifikan minat belajar antara siswa kelas X SMAN 1 Way Tuba yang belajar menggunakan model TGT dengan konvensional. Apriyanto (2015) juga mengemukakan bahwa hasil belajar geografi siswa kelas XI IPS 2 yang belajar dengan pembelajaran $P B L$ lebih tinggi daripada siswa yang belajar secara konvensional.

Perbedaan penelitian ini dengan penelitian Mirza (2009) adalah jenis penelitian yang digunakan. Pada penelitian ini termasuk quasi eksperimen, sedangkan penelitian Mirza (2009) termasuk penelitian tindakan kelas. Sintaks pembelajaran yang diterapkan memiliki persamaan dan mampu meningkatkan hasil belajar siswa, sehingga peneliti merujuk sebagai peneli- tian terdahulu dalam penelitian ini. Perbedaan penelitian ini dengan Utami (2014) adalah model yang diterapkan dan variabel yang diukur. Utami (2014) menerapkan model $T G T$ tanpa dikombinasi dengan model pembelajaran lain, sedangkan pada penelitian ini mengkombinasikan model $P B L$ dengan TGT. Utami (2014) dalam penelitiannya mengukur minat belajar, sedangkan penelitian ini mengukur dua variabel yaitu hasil dan minat belajar. Hasil penelitian Utami (2014), yaitu rata-rata minat belajar siswa kelas eksperimen adalah 38,21 dan kelas kontrol 31,30. Sedangkan hasil dari penelitian ini yang mengkombinasikan model $P B L$ dengan TGT memiliki rata-rata minat belajar pada kelas eksperimen adalah 36,8 dan kelas kontrol 30,4. Perbedaan penelitian ini dengan Apriyanto (2015) adalah model yang diterapkan dan variabel yang diukur. Apriyanto (2015) menerapkan model $P B L$ tanpa dikombinasi dengan model lain, dan variabel yang diukur adalah hasil belajar. Hasil penelitian Apriyanto (2015) yaitu nilai rata-rata gain score kelas eksperimen adalah 35,17 dan kelas kontrol 24,83. Sedangkan hasil dari penelitian ini memiliki rata-rata gain score pada kelas eksperimen yaitu 19,3 dan kelas kontrol 6,25.

Melalui penerapan kombinasi model Problem Based Learning dengan Team Games Tournament, dimensi kegembiraan dalam kegiatan belajar akan muncul ketika sintaks ketiga dari model $P B L$ disisipi oleh turnamen, sesuai dengan pendapat (Ehlers, 2004) "Melaksanakan pembelajaran dalam bentuk permainan dapat membuat siswa merasa senang". Pada tahap turnamen, setiap siswa ber- 
tanggung jawab untuk dapat menjawab pertanyaan-pertanyaan yang telah disiapkan oleh guru. Sehingga setiap siswa harus menguasai materi yang telah disampaikan guru dan permasalahan yang telah dipecahkan secara kelompok. Kelebihan dari turnamen pada model pembelajaran ini, yaitu: 1) melatih siswa bertanggung jawab atas penguasaan konsep secara individu; 2) menciptakan suasana belajar yang rileks; 3) menambah pemahaman materi, untuk mempersiakan presentasi di depan kelas; 4) menumbuhkan semangat belajar siswa.

Berdasarkan kelebihan-kelebihan di atas, pelaksanaan model pembelajaran $P B L$ dengan pembelajaran kooperatif $T G T$ dapat menghasilkan sinergi yang kuat dan hasil yang positif. Kegiatan pembelajaran yang menyenangkan mampu menumbuhkan semangat dan minat belajar siswa sehingga mampu meningkatkan hasil belajar siswa. Hal ini didukung oleh penelitian terdahulu yang dilakukan oleh M. Mirza berjudul perpaduan metode pembelajaran berbasis masalah dan turnamen permainan tim mampu meningkatkan hasil belajar biologi siswa kelas X SMA Al-Islam 2 Surakarta. Pada penelitian ini hasil belajar biologi siswa mengalami peningkatan setelah diterapkannya metode pembelajaran berbasis masalah dan turnamen permainan tim.

\section{KESIMPULAN}

Berdasarkan rumusan masalah dan hasil penelitian maka dapat disimpulkan bahwa kelas XI IPS yang mengikuti pembelajaran dengan kombinasi model $P B L$ dengan $T G T$ memiliki hasil dan mi- nat belajar lebih tinggi daripada siswa yang menggunakan pembelajaran konvensional di MAN Rejotangan Kabupaten Tulungagung. Berikut merupakan beberapa saran terkait penerapan kombinasi model $P B L$ dengan $T G T$, yaitu: 1) bagi sekolah, diharapkan dapat berperan sebagai motor dan inisiator kepada guru untuk memakai kombinasi model $P B L$ dengan $T G T$ pada saat mengajar terutama pada karakteristik kelas yang kurang memiliki minat belajar. Langkah-langkah yang dapat dilakukan oleh sekolah di antaranya yaitu mendatangkan pembicara yang berkompeten dalam pembelajaran kombinasi model $P B L$ dengan $T G T$, mengirim salah satu guru untuk mengikuti pelatihan model pembelajaran tersebut dan membentuk forum MGMP mini untuk membahas penerapan model-model pembelajaran pada kegiatan pembelajaran di sekolah; 2) bagi guru, terutama pada guru mata pelajaran geografi, diharapkan dapat menerapkan model pembelajaran kombinasi model $P B L$ dengan $T G T$ sebagai alternatif dalam praktek pembelajaran; 3) bagi peneliti selanjutnya, diharapkan agar melakukan penelitian kombinasi model $P B L$ dengan $T G T$ dengan variabel yang lain atau menambahkan variabel, melakukan penelitian dengan materi atau kompetensi dasar yang berbeda, melakukan penelitian pada kelas atau sekolah lain yang karakteristiknya berbeda agar dapat diketahui secara lanjut kelebihan kombinasi model $P B L$ dengan $T G T$.

\section{DAFTAR RUJUKAN}

Apriyanto, Bejo. 2015. Pengaruh Model Pembelajaran Problem Based Learning trhadap Hasil Belajar Geografi Siswa SMA. Tesis tidak 
Rika Hajizah Purba, Ach. Fatchan, Singgih Susilo. Pengaruh Kombinasi Model Problem Based Learning Dengan Team Games Tournament Terhadap Hasil Dan Minat Belajar Geografi Siswa MAN Rejotangan Kabupaten Tulunggung

diterbitkan. Malang: Universitas Negeri Malang.

Devries. $1976 . \quad$ Teams-GamesTournament: A Gaming Technique That Fosters Learning. Simulation Gaming 1976 7: 21. DOI: $10.1177 / 104687817600700102$. (online)

http://sag.sagepub.com/content/7/1/ 21. Diakses 15 Agustus 2015.

Ehlers, Valerie. 2004. Teaching Aspects of Health Care. South Africa: Juta Academic.

Mirza, M. 2009. Peningkatan Hasil Belajar Biologi Pokok Bahasan Pencemaran Lingkungan dengan PTK Melalui Perpaduan Metode Pembelajaran Berbasis Masalah dan Turnamen Permainan Tim pada Siswa Kelas X SMA Al-Islam 2 Surakarta. Jurnal. Surakarta: Universitas Muhammadiyah Surakarta.

Slavin, R.E. 2005. Cooperative Learning Teori, Riset dan Praktik. Bandung: Nusa Media.

Soemanto, Wasty. 1983. Psikologi Pendidikan. Jakarta: Renika Cipta.

Sumarmi. 2012. Model-Model Pembelajaran Geografi. Malang: Aditya Media Publishing.

Utami, Dian. 2014. Pengaruh Model Pembelajaran Team Games Tournament terhadap Minat Belajar Geografi Siswa SMA. Tesis tidak diterbitkan. Malang: Universitas Negeri Malang. 